\title{
Health-Related Quality of Life for People With Acute and Chronic Illnesses During the COVID-19 Pandemic
}

\author{
Marie Claire O'Dwyer, MB, Kate Meixner, MD, Laura Crespo Albiac, MD, \\ Christelle El Khoury, MD, J. Nicoll Capizzano, MD, Manasi Ramakrishnan, MBBS, \\ Cullen Salada, MD, Wendy Furst, MS, Elizabeth Haro, MPH, \\ Martha Alves, MPH, MSW, Ananda Sen, PhD, and Diane M. Harper, MD, MPH, MS
}

Background: Health-related quality of life (HRQoL) for adults with chronic and acute illnesses informs health and economic policy for pandemic recovery. Our primary aim was to compare HRQoL of 3 illness groups of outpatient adults: those with diabetes, those who survived a hospitalization for COVID-19, and those who had a respiratory virus not COVID-19. The secondary aim was to compare the group domain summary scores to the referent general population.

Methods: We identified the 3 groups from the electronic medical record and invited them to complete the SF-36 survey. Analysis of variance and post hoc testing was used for univariate analyses followed by linear regression.

Results: One hundred thirty-two adults completed the survey. The groups differed least for physical functioning and most for emotional/mental health. The hospitalized group had the greatest limitation in role due to emotional issues. All groups had significantly lower social functioning scores than the general population. Linear regression showed lower HRQoL domain score in role limitations due to emotional issues adjusted for age, race, and gender for the hospitalized group.

Conclusion: SF-36 scores show the decrease in HRQoL that outpatient adults have suffered, mostly in the emotional domain, regardless of illness group during the COVID-19 pandemic. ( $\mathrm{J}$ Am Board Fam Med 2021;34:509-521.)

Keywords: Acute Disease, Chronic Disease, CoVID-19, Linear Models, Outpatients, Pandemics, Primary Health Care, Quality of Life, Surveys and Questionnaires

\section{Introduction}

Severe acute respiratory syndrome coronavirus 2 (SARS-CoV-2), also known as 2019 novel coronavirus (COVID, COVID-19), is the pandemic of the 21st century. Many studies have been published detailing logistic restructuring of health care because of COVID, prediction models of transmission with

This article was externally peer reviewed.

Submitted 15 November 2020; revised 5 January 2021; accepted 8 January 2021.

From the Department of Family Medicine, University of Michigan, Ann Arbor (MCO, KM, LCA, CEK, JNC, MR, CS, WF, EH, MA, AS, DMH).

Funding: Supported by grants from the National Cancer Institute (P30CA046592) and the National Center for Advancing Translational Science (UL1TR001070).

Conflict of interest: None.

Corresponding author: Diane M. Harper, MD, MPH, MS, University of Michigan, Ann Arbor (E-mail: diane.m. harper@gmail.com). resulting hospital resource use, and clinical trials of therapeutic inpatient drugs. ${ }^{1-3}$ While a few studies have shown COVID-related changes in health outcomes, ${ }^{4-6}$ no study has evaluated the effects of COVID on self-perceived health-related quality of life (HRQoL) in outpatients with chronic and acute diseases using a measure that can be directly imported into health economic models of future pandemic planning.

The Short-Form Health Survey (SF-36), ${ }^{7}$ an HRQoL questionnaire, was created and validated $^{8}$ reporting scores for 8 domains of physical and mental health that are self-assessed. The scores themselves have been used alone as quality metrics for monitoring health and patient outcomes over time ${ }^{9}$ or as a utility measure to adjust cost models for health care policy decisions. ${ }^{10,11}$ Quality of life measures have the greatest impact 
Table 1. Demographic Descriptors of the Population Groups

\begin{tabular}{|c|c|c|c|c|c|c|c|c|c|c|}
\hline \multirow[b]{3}{*}{ Age (years), mean, SD } & \multirow{2}{*}{\multicolumn{2}{|c|}{$\frac{\text { Type } 2 \text { Diabetes (D) }}{\mathrm{n}=50}$}} & & \multicolumn{3}{|c|}{ SARS-CoV-2 Hospitalized (H) } & \multicolumn{2}{|c|}{ Respiratory Illness (R) } & \multirow{2}{*}{\multicolumn{2}{|c|}{$P$ Value }} \\
\hline & & & & & & & & & & \\
\hline & 61.17 & 12.61 & * & 58.49 & 10.93 & & 50.50 & 19.65 & * & $<0.05$ \\
\hline \multicolumn{11}{|l|}{ Race (n, \%) } \\
\hline White & 42 & 84.0 & * & 19 & 48.7 & * & 32 & 78.1 & & $<0.01$ \\
\hline Black & 3 & 6.0 & & 15 & 38.5 & & 7 & 17.1 & & \\
\hline $\begin{array}{l}\text { Other (Hispanic, Asian, } \\
\text { Alaska Native, American } \\
\text { Indian, MENA, Native } \\
\text { Hawaiian, Pacific Islander, } \\
\text { multirace) }\end{array}$ & 5 & 10.0 & & 5 & 12.8 & & 2 & 4.9 & & \\
\hline Gender (n, \%) & & & & & & & & & & $<0.05$ \\
\hline Female & 31 & 68.0 & * & 17 & 41.5 & * & 25 & 60.1 & & \\
\hline Male & 16 & 32.0 & & 24 & 58.5 & & 16 & 39.0 & & \\
\hline Partner status (n, \%) & & & & & & & & & & NS \\
\hline Partnered & 30 & 61.2 & & 28 & 68.3 & & 29 & 70.7 & & \\
\hline Single & 19 & 38.8 & & 13 & 31.7 & & 12 & 29.3 & & \\
\hline Occupation (n, \%) & & & & & & & & & & NS \\
\hline Employed & 12 & 26.7 & & 15 & 41.7 & & 18 & 46.2 & & \\
\hline Student & 1 & 2.2 & & 0 & 0.0 & & 2 & 5.1 & & \\
\hline Unemployed & 7 & 15.6 & & 5 & 13.9 & & 2 & 5.1 & & \\
\hline Retired/disabled & 25 & 55.6 & & 16 & 44.4 & & 17 & 43.6 & & \\
\hline \multicolumn{11}{|l|}{ Income (n, \%) } \\
\hline Under $\$ 10 \mathrm{~K}$ & 4 & 8.5 & & 3 & 7.9 & & 3 & 7.3 & & NS \\
\hline$\$ 10 \mathrm{~K}-\$ 49,999$ & 9 & 19.2 & & 6 & 15.8 & & 15 & 36.6 & & \\
\hline$\$ 50 \mathrm{~K}-\$ 99,999$ & 21 & 44.7 & & 15 & 39.5 & & 15 & 36.6 & & \\
\hline$\$ 100,000+$ & 13 & 27.7 & & 14 & 36.8 & & 8 & 19.5 & & \\
\hline Education (n, \%) & & & & & & & & & & NS \\
\hline High school or less & 9 & 18.0 & & 3 & 7.5 & & 6 & 14.6 & & \\
\hline Some college & 16 & 32.0 & & 15 & 37.5 & & 11 & 26.8 & & \\
\hline Completed college & 11 & 22.0 & & 13 & 32.5 & & 15 & 36.6 & & \\
\hline Postcollege & 14 & 28.0 & & 9 & 22.5 & & 9 & 22.0 & & \\
\hline Insurance (n, \%) & & & & & & & & & & NS \\
\hline Private & 29 & 58.0 & & 25 & 61.0 & & 21 & 51.2 & & \\
\hline $\begin{array}{l}\text { Federal (Medicaid, Medicare, } \\
\text { tribal) }\end{array}$ & 20 & 40.0 & & 16 & 39.0 & & 20 & 48.8 & & \\
\hline None & 1 & 2.0 & & 0 & 0.0 & & 0 & 0.0 & & \\
\hline Length of time with PCP (n, \%) & & & & & & & & & & NS \\
\hline 3 or fewer years & 18 & 36.0 & & 15 & 37.5 & & 14 & 34.2 & & \\
\hline More than 3 years & 32 & 64.0 & & 25 & 62.5 & & 27 & 65.9 & & \\
\hline Number in household (n, \%) & & & & & & & & & & NS \\
\hline 2 or fewer persons & 33 & 66.0 & & 26 & 66.7 & & 22 & 55.0 & & \\
\hline More than 2 persons & 17 & 34.0 & & 13 & 33.3 & & 18 & 45.0 & & \\
\hline Tobacco use (n, \%) & & & & & & & & & & NS \\
\hline Current/ever & 11 & 22.5 & & 10 & 24.4 & & 17 & 41.5 & & \\
\hline Never & 38 & 77.6 & & 31 & 75.6 & & 24 & 58.5 & & \\
\hline
\end{tabular}

*Significant two-way comparisons by post hoc testing.

NS, not significant; PCP, primary care physician; SD, standard deviation.

on economic analyses when chronic conditions and long-term sequelae from acute diseases are modeled.
Individuals with chronic diseases such as type 2 diabetes have a decreased quality of life ${ }^{12}$ due to their disease, and while they are routinely managed 
in the primary care office, this option was restricted for many during the pandemic. In addition, individuals with diabetes who contract COVID are in a high-risk category for hospitalization and severe respiratory symptoms, increasing their anxiety burden. Acute respiratory illnesses, on the other hand, are usually self-contained and rarely affect a person's long-term quality of life. During COVID, though, patients with acute respiratory symptoms did not know if the symptoms were due to COVID or a community-acquired viral illness, increasing temporary anxiety. Finally, those who survived a hospitalization for COVID, some of whom were intubated, would be expected to have the lowest HRQoL due to physical deterioration, social isolation, long-term COVID affects, and uncertainty about future health.

The primary aim of this study was to compare the self-reported HRQoL among 3 groups with distinct burdens of illness during the COVID-19 pandemic by health domain in a large midwestern academic health system. The secondary aim was to compare the 8 domains of HRQoL among the 3 subject groups to the general population.

\section{Methods}

\section{Study Population}

All people recruited to the study were communitydwelling adults (18 years and older) associated with a large Midwest academic medical center who had 1 of 3 conditions. They had either the chronic condition of type 2 diabetes mellitus (D), an acute simple respiratory infection of non-COVID-19 coronavirus or rhinoviruses (R), or survived a hospitalization for COVID-19 (H). These 3 distinct groups offered a spectrum of disease severity that has not been previously explored.

The COVID-19 (H) group consisted of patients who survived their hospitalization for positively diagnosed COVID-19 (see Appendix for the set of diagnostic criteria). They were identified from the electronic medical record (EMR) by the date of COVID-19 diagnosis that was recorded between March 20, 2020 and May 31, 2020. Those in the respiratory (R) group were identified from the EMR by the date of diagnosis with a coronaviruses other than COVID-19 (HKU1, 2229e, NL63, or OC43) or rhinovirus between January 1, 2020 and September 1, 2020. Those in the diabetic (D) group were identified from the EMR on June 3, 2020 and had seen their family physician for diabetes at least once in the past 3 years.

\section{Recruitment and Enrollment}

The study was exempt from an institutional review board (HUM00182620, June 2, 2020). Participants were initially contacted by phone or e-mail in a rolling fashion starting between June 13, 2020 through September 14, 2020 after the first wave of COVID ${ }^{13}$ until at least 41 people completed the survey in each of the groups. There was at least 2 months from hospitalization before the COVID group completed the survey. All were invited to complete an anonymous online survey. They were contacted up to 3 times over a 2-week period. For those who agreed to participate, a reminder e-mail to complete the survey was sent 2 weeks later. Patients that required an interpreter were excluded from enrollment.

\section{Survey}

The online survey included basic demographic questions and items regarding how their health had changed over the past 4 months due to the COVID-19 pandemic. The validated SF-36 v1 from Rand was used, ${ }^{7}$ in which scores for each of 8 domains are summed and transformed into a Likert scale ranging from 0 (worst) to 100 (best) for analysis. ${ }^{14}$ All scores were recorded according to scale instructions such that higher scores indicated more favorable health. The questionnaire was estimated to take between 15 and 20 minutes to complete.

The 8 domains assessed encompass physical functioning, role limitations due to physical problems, bodily pain, general health perceptions, vitality, social functioning, role limitations due to emotional problems, and mental health.

\section{Survey Administration}

The survey was entered into Qualtrics, a secure, web-based application designed to support electronic data capture for research projects and piloted before enrollment. Participants completed the survey either through a link sent by e-mail or by phone interview, according to their preference.

\section{Statistical Analysis}

An a priori power calculation was performed that estimated the need for a minimum of 41 respondents per group for a minimum effect size between 2 arms of 15 units (published SD of 21 [RAND scoring $]^{15}$ ) with a power of $80 \%$ and a level of 
Table 2. Change in Health Status During Sars-CoV-2 Pandemic

\begin{tabular}{|c|c|c|c|c|c|c|c|c|c|c|}
\hline \multirow{3}{*}{$\begin{array}{l}\text { Change in general } \\
\text { health over the past } \\
\text { year }^{\ddagger} \text { (mean, SD) }\end{array}$} & \multirow{2}{*}{\multicolumn{2}{|c|}{$\frac{\text { Type } 2 \text { Diabetes (D) }}{\mathrm{n}=50}$}} & & \multirow{2}{*}{\multicolumn{2}{|c|}{$\frac{\text { SARS-CoV-2 Hospitalized }(\mathrm{H})}{\mathrm{n}=41}$}} & & \multirow{2}{*}{\multicolumn{2}{|c|}{$\frac{\text { Respiratory Illness (R) }}{\mathrm{n}=41}$}} & & \multirow{3}{*}{$\frac{P \text { Value }}{<0.01}$} \\
\hline & & & & & & & & & & \\
\hline & 43.5 & 19.4 & * & 28.7 & 22.8 & ${ }^{*} \dagger$ & 43.3 & 26.8 & $\dagger$ & \\
\hline $\begin{array}{l}\text { Compared to the } \\
\text { general population } \\
\text { mean score of } 59.14 \\
(\text { SD 23.12) }(P \text { value })\end{array}$ & $<0.001$ & & & $<0.001$ & & & $<0.001$ & & & \\
\hline $\begin{array}{l}\text { How much of the } \\
\text { change is attributed } \\
\text { to COVID? }{ }^{\S} \text { (mean, } \\
\text { SD) }\end{array}$ & 3.9 & 1.2 & * & 4.7 & 1.4 & ${ }^{*}+$ & 3.7 & 1.6 & $\dagger$ & $<0.01$ \\
\hline
\end{tabular}

*Significant two-way comparisons by post hoc testing.

${ }^{\dagger}$ Significant two-way comparisons by post hoc testing.

${ }^{\ddagger} 0$, none to 100 , completely.

${ }^{\$} 1=$ none, 2 = little, $3=$ some, $4=$ moderate, $5=$ a lot, $6=$ almost all.

$\mathrm{SD}$, standard deviation.

significance of $2 \%$, accounting for multiple comparisons for self-reported overall change in health status. Descriptive data using means and frequencies were reported followed by one-way ANOVA and post hoc testing for significance or KruskalWallis comparison of frequencies. We compared the summary domain scores to the reference general population (RAND scoring) ${ }^{15}$ using a $t$-test for single means. Linear regression modeling predicted each of the summary domain scores adjusting for significant descriptors among the groups. All data were analyzed with Statistica v13. ${ }^{16}$

\section{Results}

\section{Descriptive}

Eight hundred and seventy-nine people were contacted until the number of surveys required for power were completed in each group. There were 183 people contacted in the diabetic group, 259 in the acute respiratory group, and 437 in the survivors of hospitalization (COVID-19 positive) group.

The 3 groups are significantly different by age, race, and gender (Table 1). The respiratory (R) group is significantly younger than the diabetic (D) group (mean, 50.5 SD [19.65] vs 61.2 [12.6], $P<.05)$ with the SARS-CoV-2 hospitalized $(\mathrm{H})$ group intermediate in age (58.5 [10.9]). The hospitalized group has a significantly greater Black population than the diabetic group $(38.5 \%$ vs $6.0 \%$, $P<.01)$. Likewise, the diabetic group has significantly more women than the hospitalized group $(41.5 \%$ vs $68.0 \%, P<.05)$. There were no differences among groups in partner status, occupation, income, education, insurance, length of time with the primary care physician, number of persons in the household, and tobacco use.

Subjective symptoms of COVID were present in all groups but differed by duration and proportion of population experienced. Symptoms of COVID were reported by all survivors of COVID hospitalization the longest at a mean 33.4 (SD 33.1) days ranging from 0 to 152 days, while all the acute respiratory non-COVID group reported symptoms for a mean of 23.8 (SD 54.4) days, with the greatest range from 0 to 211 days, and the non-COVID diabetic group reported symptoms for a mean of 7.8 (SD 16.9) days, ranging from 0 to 72 days where $77 \%$ had no days of symptoms and none tested positive for COVID.

The duration of hospitalization differed among those who survived COVID, ranging from 1 to 66 days (mean, 13.3 SD 16.3). Twenty percent of this group was intubated, and intubation only occurred for those whose hospitalization was 18 days or longer. The survivors of COVID hospitalization self-reported significantly worse physical health due to COVID than the acute respiratory or diabetic groups (Tukey post hoc $\mathrm{P}<.001$ ). But all 3 groups self-rated equally the impact of COVID on mental health, social life, and ability to exercise, volunteer, or provide care to children or elders.

\section{SF-36 Results}

The single item question reflecting on their own health status over the past year showed that all 3 


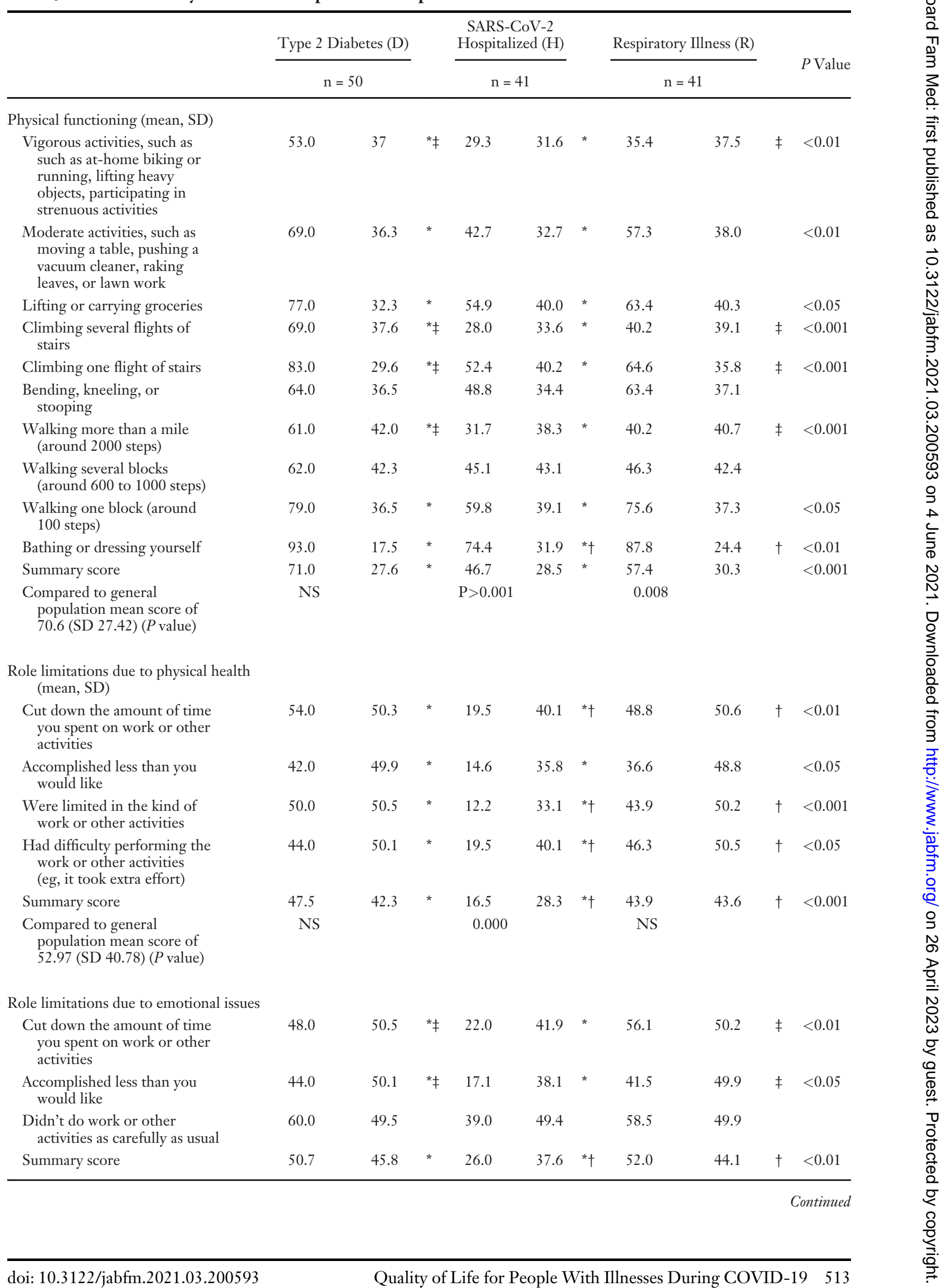




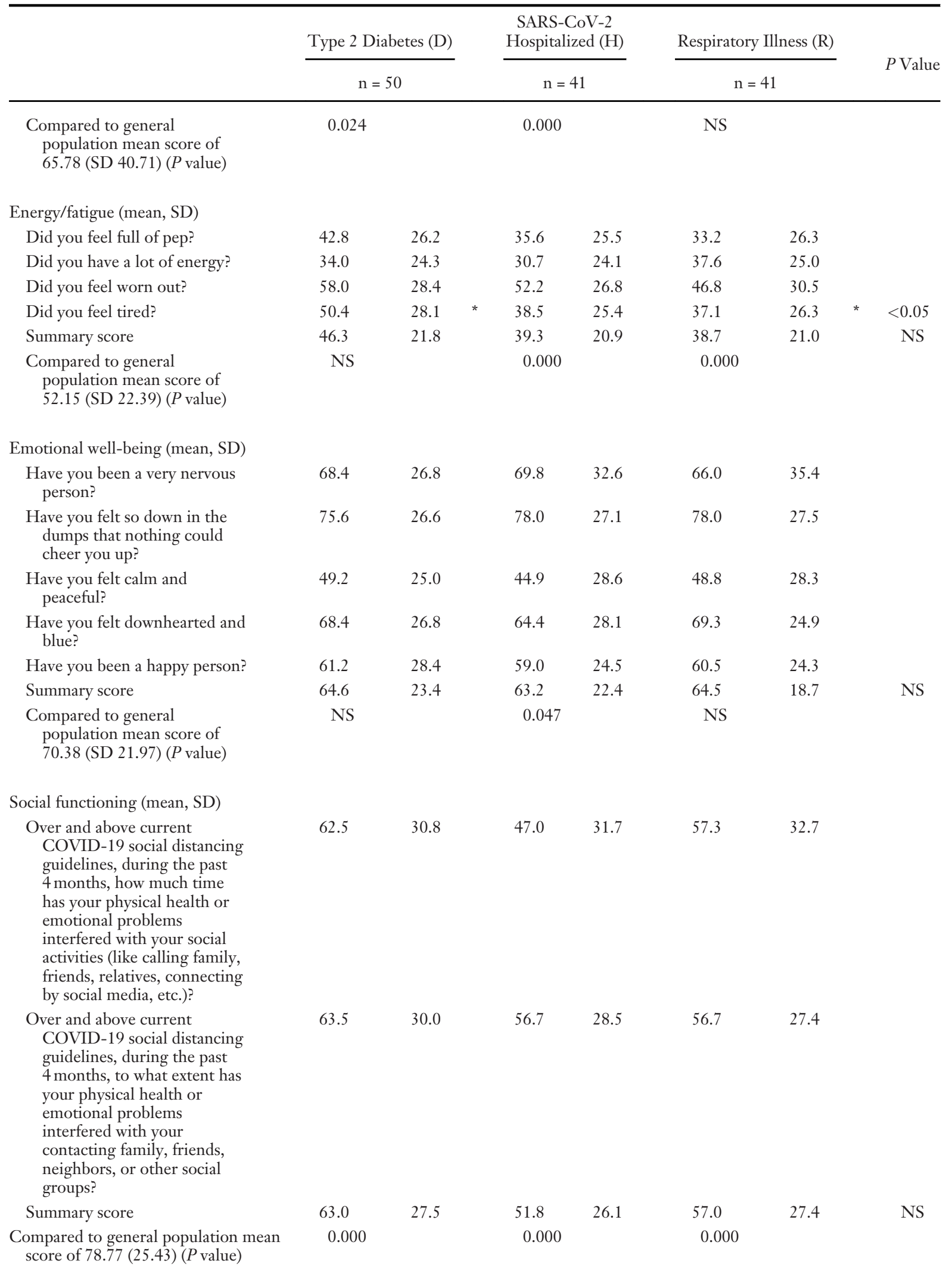




\begin{tabular}{|c|c|c|c|c|c|c|c|c|c|c|}
\hline \multirow{3}{*}{ Pain (mean, SD) } & \multicolumn{2}{|c|}{ Type 2 Diabetes (D) } & & \multicolumn{2}{|c|}{$\begin{array}{l}\text { SARS-CoV-2 } \\
\text { Hospitalized (H) }\end{array}$} & & \multicolumn{2}{|c|}{ Respiratory Illness (R) } & & \multirow{2}{*}{$P$ Value } \\
\hline & \multicolumn{2}{|c|}{$\mathrm{n}=50$} & & \multicolumn{2}{|c|}{$\mathrm{n}=41$} & & \multicolumn{2}{|c|}{$\mathrm{n}=41$} & & \\
\hline & & & & & & & & & & \\
\hline $\begin{array}{l}\text { How much bodily pain have } \\
\text { you had during the past } \\
4 \text { months? }\end{array}$ & 67.5 & 26.4 & & 52.4 & 30.5 & & 60.4 & 30.6 & & \\
\hline $\begin{array}{l}\text { During the past } 4 \text { months, } \\
\text { how much did pain } \\
\text { interfere with your normal } \\
\text { activities (including both } \\
\text { work outside the home and } \\
\text { housework)? }\end{array}$ & 58.0 & 27.2 & & 45.4 & 24.5 & & 51.7 & 27.2 & & \\
\hline Summary score & 62.7 & 25.1 & * & 48.9 & 26.1 & * & 56 & 27.3 & & $<0.05$ \\
\hline $\begin{array}{l}\text { Compared to general } \\
\text { population mean score of } \\
70.77 \text { (SD 25.46) }(P \text { value })\end{array}$ & 0.029 & & & 0.000 & & & 0.00 & & & \\
\hline \multicolumn{11}{|l|}{ General health (mean, SD) } \\
\hline $\begin{array}{l}\text { In general, would you say } \\
\text { your health is (1, excellent } \\
\text { to } 5 \text {, poor scale) }\end{array}$ & 47.5 & 20.4 & & 37.2 & 23.1 & & 39.0 & 21.0 & & \\
\hline $\begin{array}{l}\text { I seem to get sick a little } \\
\text { easier than other people }\end{array}$ & 69.5 & 30.0 & & 62.2 & 31.2 & & 36.6 & 33.1 & & \\
\hline $\begin{array}{l}\text { I am as healthy as anybody I } \\
\text { know }\end{array}$ & 49.5 & 26.5 & & 46.3 & 31.4 & & 35.4 & 27.4 & & \\
\hline $\begin{array}{l}\text { I expect my health to get } \\
\text { worse }\end{array}$ & 60.5 & 31.2 & * & 66.5 & 27.2 & $\dagger$ & 54.3 & 32.1 & *† & $<0.001$ \\
\hline My health is excellent & 39.5 & 32.0 & & 36.0 & 33.6 & & 34.8 & 32.1 & & \\
\hline Summary score & 53.3 & 23.5 & * & 49.6 & 22.9 & & 40.0 & 21.2 & * & $<0.05$ \\
\hline $\begin{array}{l}\text { Compared to general } \\
\text { population mean score of } \\
56.99(\mathrm{SD} 21.11)(P \text { value })\end{array}$ & NS & & & 0.04 & & & 0.00 & & & \\
\hline
\end{tabular}

*Significant two-way comparisons by post hoc testing. ${ }^{\dagger}$ Significant two-way comparisons by post hoc testing. ${ }^{\ddagger}$ Significant two-way comparisons by post hoc testing. NS, no significant differences.

groups reported a change in health status that was significantly lower than the mean reference population score of 59.14 (SD 23.12) (D: 43.5 [19.4], H: 28.7 [22.8], and R: 43.3 [26.8], $P<.001$; Table 2). Among groups, the hospitalized group had the greatest significant decrease in health status scores compared with both the respiratory and diabetic groups (H: 28.7 [22.8] vs R: 43.3 [26.8] and D: 43.5 [19.4], respectively, Tukey post hoc $P<.01)$.

The HRQoL scores for the 8 domains are presented in Table 3. Compared with the general reference population in the United States, the hospitalized group had significantly lower quality of life in all 8 domains, the respiratory group in 5 domains, and the diabetic group in 3 domains. The diminished quality of life domains for the acute respiratory group are physical functioning, energy/fatigue, and current general health domains, whereas the diabetic group has significantly lower quality of life scores in the domain of role limitations due to emotional issues. All 3 groups had significantly reduced quality of life in the pain and social functioning domains.

The domains differed by summary score among the groups. Significant differences occurred for the domains of role limitations due to physical health between diabetic versus hospitalized groups and between hospitalized versus respiratory groups (Table 3). Role limitations due to emotional issues (diabetic vs hospitalized, hospitalized vs 
Table 4. Linear Regression Models Predicting Quality of Life by Domain Adjusted for Age, Gender, Race, and Population Group

\begin{tabular}{|c|c|c|c|c|c|c|c|c|c|c|c|c|}
\hline & \multicolumn{4}{|c|}{ Physical Functioning } & \multicolumn{4}{|c|}{$\begin{array}{l}\text { Role Limitations Due to } \\
\text { Physical Health }\end{array}$} & \multicolumn{4}{|c|}{ Energy/Fatigue } \\
\hline & $\begin{array}{c}B \\
\text { Parameter }\end{array}$ & $\begin{array}{l}95 \% \\
\text { LL }\end{array}$ & $\begin{array}{l}95 \% \\
\text { UL }\end{array}$ & $\begin{array}{c}P \\
\text { Value }\end{array}$ & $\begin{array}{c}B \\
\text { Parameter }\end{array}$ & $\begin{array}{c}95 \% \\
\quad L L\end{array}$ & $\begin{array}{l}95 \% \\
\text { UL }\end{array}$ & $\begin{array}{c}P \\
\text { Value }\end{array}$ & $\begin{array}{c}\text { ß } \\
\text { Parameter }\end{array}$ & $\begin{array}{l}95 \% \\
\text { LL }\end{array}$ & $\begin{array}{l}95 \% \\
\text { UL }\end{array}$ & $\begin{array}{c}P \\
\text { Value }\end{array}$ \\
\hline Age (years) & -0.64 & -1.01 & -0.27 & $<0.0001$ & -0.17 & -0.68 & 0.34 & 0.51 & 0.24 & -0.02 & 0.51 & 0.07 \\
\hline \multicolumn{13}{|l|}{ Gender } \\
\hline Referent: Male & 0.00 & & & & 0.00 & & & & 0.00 & & & \\
\hline Female & 10.62 & -0.82 & 22.05 & 0.07 & 8.68 & -7.04 & 24.40 & 0.28 & 3.78 & -4.43 & 12.00 & 0.36 \\
\hline \multicolumn{13}{|l|}{ Race } \\
\hline Referent: White & 0.00 & & & & 0.00 & & & & 0.00 & & & \\
\hline Black & -10.94 & -26.00 & 4.13 & 0.15 & 0.94 & -19.77 & 21.65 & 0.93 & 14.96 & 4.15 & 25.78 & 0.01 \\
\hline Other & -1.63 & -22.67 & 19.41 & 0.88 & -3.90 & -32.82 & 25.03 & 0.79 & 3.68 & -11.43 & 18.80 & 0.63 \\
\hline \multicolumn{13}{|l|}{ Group } \\
\hline Referent: Respiratory & 0.00 & & & & 0.00 & & & & 0.00 & & & \\
\hline Diabetic & 14.50 & 0.10 & 28.89 & 0.05 & -2.80 & -22.58 & 16.99 & 0.78 & 3.14 & -7.20 & 13.48 & 0.55 \\
\hline \multirow[t]{3}{*}{ COVID hospitalized } & 2.81 & -11.59 & 17.20 & 0.70 & -19.41 & -39.20 & 0.38 & .05 & -3.34 & -13.68 & 6.99 & 0.52 \\
\hline & \multicolumn{4}{|c|}{$\begin{array}{l}\text { Role Limitations Due to } \\
\text { Emotional Issues }\end{array}$} & \multicolumn{4}{|c|}{ Emotional Well-Being } & \multicolumn{4}{|c|}{ Social Functioning } \\
\hline & $\begin{array}{c}B \\
\text { Parameter }\end{array}$ & $\begin{array}{l}95 \% \\
\mathrm{LL}\end{array}$ & $\begin{array}{l}95 \% \\
\text { UL }\end{array}$ & $\begin{array}{c}P \\
\text { Value }\end{array}$ & $\begin{array}{c}ß \\
\text { Parameter }\end{array}$ & $\begin{array}{l}95 \% \\
\mathrm{LL}\end{array}$ & $\begin{array}{l}95 \% \\
\text { UL }\end{array}$ & $\begin{array}{c}P \\
\text { Value }\end{array}$ & $\begin{array}{c}\beta \\
\text { Parameter }\end{array}$ & $\begin{array}{l}95 \% \\
\text { LL }\end{array}$ & $\begin{array}{l}95 \% \\
\text { UL }\end{array}$ & $\begin{array}{c}P \\
\text { Value }\end{array}$ \\
\hline Age (years) & -0.24 & -0.81 & 0.33 & 0.41 & 0.46 & 0.21 & 0.70 & $<0.0001$ & -0.03 & -0.38 & 0.32 & 0.87 \\
\hline \multicolumn{13}{|l|}{ Gender } \\
\hline Referent: Male & 0.00 & & & & 0.00 & & & & 0.00 & & & \\
\hline Female & 0.09 & -17.41 & 17.59 & 0.99 & -4.16 & -11.78 & 3.46 & 0.28 & 10.16 & -0.52 & 20.84 & 0.06 \\
\hline \multicolumn{13}{|l|}{ Race } \\
\hline Referent: White & 0.00 & & & & 0.00 & & & & 0.00 & & & \\
\hline Black & 4.26 & -18.79 & 27.31 & 0.71 & 13.50 & 3.46 & 23.53 & 0.01 & 6.22 & -7.85 & 20.29 & 0.38 \\
\hline Other & 14.22 & -17.98 & 46.42 & 0.38 & 1.07 & -12.95 & 15.08 & 0.88 & 7.19 & -12.46 & 26.85 & 0.47 \\
\hline \multicolumn{13}{|l|}{ Group } \\
\hline Referent: Respiratory & 0.00 & & & & 0.00 & & & & 0.00 & & & \\
\hline Diabetic & -2.67 & -24.70 & 19.36 & 0.81 & -2.88 & -12.46 & 6.71 & 0.55 & 6.23 & -7.22 & 19.67 & 0.36 \\
\hline \multirow[t]{3}{*}{ COVID hospitalized } & -25.93 & -47.96 & -3.90 & 0.02 & -7.98 & -17.57 & 1.61 & 0.10 & -4.97 & -18.42 & 8.48 & 0.46 \\
\hline & \multicolumn{4}{|c|}{ Pain } & \multicolumn{4}{|c|}{ Current General Health } & \multicolumn{4}{|c|}{ Change in Health Status } \\
\hline & $\begin{array}{c}\text { B } \\
\text { Parameter }\end{array}$ & $\begin{array}{c}95 \% \\
\text { LL }\end{array}$ & $\begin{array}{l}95 \% \\
\text { UL }\end{array}$ & $\begin{array}{c}P \\
\text { Value }\end{array}$ & $\begin{array}{c}\text { B } \\
\text { Parameter }\end{array}$ & $\begin{array}{c}95 \% \\
\text { LL }\end{array}$ & $\begin{array}{l}95 \% \\
\text { UL }\end{array}$ & $\begin{array}{c}P \\
\text { Value }\end{array}$ & $\begin{array}{c}\text { B } \\
\text { Parameter }\end{array}$ & $\begin{array}{l}95 \% \\
\mathrm{LL}\end{array}$ & $\begin{array}{l}95 \% \\
\text { UL }\end{array}$ & $\begin{array}{c}P \\
\text { Value }\end{array}$ \\
\hline Age (years) & -0.20 & -0.54 & 0.14 & 0.24 & 0.15 & -0.14 & 0.45 & 0.31 & -0.15 & -0.45 & 0.15 & 0.33 \\
\hline \multicolumn{13}{|l|}{ Gender } \\
\hline Referent: Male & 0.00 & & & & 0.00 & & & & 0.00 & & & \\
\hline Female & 14.28 & 3.76 & 24.79 & 0.01 & 4.12 & -5.07 & 13.32 & 0.38 & 5.90 & -3.36 & 15.16 & 0.21 \\
\hline \multicolumn{13}{|l|}{ Race } \\
\hline Referent: White & 0.00 & & & & 0.00 & & & & 0.00 & & & \\
\hline Black & 2.02 & -11.83 & 15.87 & 0.77 & -1.92 & -14.03 & 10.19 & 0.75 & 12.17 & -0.03 & 24.37 & 0.05 \\
\hline Other & 5.40 & -13.94 & 24.75 & 0.58 & -3.76 & -20.67 & 13.16 & 0.66 & -0.59 & -17.63 & 16.44 & 0.94 \\
\hline \multicolumn{13}{|l|}{ Group } \\
\hline Referent: Respiratory & 0.00 & & & & 0.00 & & & & 0.00 & & & \\
\hline Diabetic & 3.08 & -10.16 & 16.31 & 0.65 & 11.10 & -0.47 & 22.68 & 0.06 & 1.42 & -10.23 & 13.08 & 0.81 \\
\hline COVID hospitalized & -3.37 & -16.61 & 9.86 & 0.61 & 11.94 & 0.37 & 23.52 & 0.04 & -15.29 & -26.95 & -3.64 & 0.01 \\
\hline
\end{tabular}

There were no significant interaction terms among age, gender, race, and group.

LL, lower limit; UL, upper limit. 
respiratory), physical functioning (diabetic vs hospitalized), pain (diabetic vs hospitalized), and general health (diabetic vs respiratory) were other significant differences in summary score quality of life among groups. Physical functioning and role limitations, both due to physical health and emotional issues, were the domains with the greatest differences among the individual component questions across all groups.

The linear regression model (Table 4) was adjusted for age, gender, race, and population group to predict overall changes in HRQoL domains among the 3 groups. Age remained significant in predicting physical functioning $(\beta=-0.64$, $P<.001)$ and emotional well-being $(B=0.46$, $P<.001)$, meaning the older the person was, the less their physical functioning was, but the greater their emotional well-being was. Females documented a higher quality of life (less pain) in the pain domain ( $\beta=14.3, P=.01)$ compared with men. Those of the Black race had a higher quality of life for both energy/fatigue $(B=15.0, P=.01)$ (less fatigue) and emotional well-being $(B=13.5, P=.01)$ (better emotional well-being).

The 3 population groups, chronic illness (D), acute simple illness $(\mathrm{R})$, and acute complex illness $(\mathrm{H})$, experienced significantly different quality of life in the domains of physical functioning, role limitations due to emotional issues, and general health after adjusting for age, gender, and race. In addition, the population groups significantly differed in the change in health status over the past 4 months. Specifically, compared with the respiratory group, the diabetic group had significantly greater physical functioning $(B=14.5, P<$ $.05)$. Compared with the respiratory group, the hospitalized group had significantly decreased quality of life for role limitations due to emotional issues $(B=-25.9$, $P=.02)$ but significantly increased general health quality of life $(B=11.9, P<.05)$. Overall, though, the hospitalized group had significantly greater decreases in quality of life as measured by a change in health status over the past 4 months, compared with the respiratory group $(B=-15.3, P=.01)$ after adjusting for age, gender, and race.

\section{Discussion}

Our work provides the first measures of the HRQoL of outpatient adult groups of 3 different disease acuities during COVID-19. Other studies have registered with Clinicaltrials.gov planning to evaluate the physical functioning and quality of life of COVID19 survivors after hospitalization (NCT04375709, NCT04376658, NCT04416464) and the effects of self-isolating at home (NCT04319211).

We have shown that community-dwelling adults with type 2 diabetes, those who survived a COVID19 hospitalization, and those who had a nonCOVID coronavirus or rhinovirus respiratory illness have distinctly different HRQoL experiences. Those with diabetes only had changes in HRQoL domains of social functioning (interfering with social activities and contacting friends/family), role limitations due to emotional issues (accomplishing less than would like), and increased bodily pain (pain interfering with daily activities). Physical functioning and role limitations due to physical health were not affected. Comparing our diabetic population's domain scores to the scores of diabetics categorized by a1c values during nonpandemic years shows that our diabetic population selfrated themselves, over and above the current COVID-19 social distancing guidelines, with lower scores for social functioning and role limitations due to emotional issues than those with the highest, most severe, a1c percentages, ${ }^{17}$ supporting our conclusion of worse HRQoL during this pandemic. Other comorbidities associated with diabetes also influence the worsening of reported HRQoL scores but in opposite domains, more in the physical component summary than the mental component summary, ${ }^{18}$ Given the nuances of HRQoL of diabetic populations, the strength of decline in our HRQoL measures in 2 mental health domains remains clinically important.

The hospitalized group surviving COVID-19 had the worst HRQoL measures for all domains, most severely with increased role limitations due to emotional issues (accomplishing less) and a decreasing self-reported change in health status over 4 months, but were the most optimistic about their current general health. Other reports of hospitalized COVID-19 patients taken within 6 months of discharge report similar decreases in emotional well-being. ${ }^{19}$

The respiratory group, on the other hand, rated their current general health the poorest of the 3 groups, with vigorous exercise such as climbing several flights of stairs or walking more than a mile as activities that matched the lowest scores of the hospitalized group. This ambulatory group attributed the significant decreases in general health to 
expecting their health to get worse, whereas the other 2 groups were significantly more optimistic. This fear seems to be associated with the decrease in feeling calm and peaceful that was noted in the emotional well-being domain. For all other health domains, though, the respiratory group matched the healthier scores of the diabetic group. This result is important for future pandemics, when those with seemingly minimal illness, but similar symptoms to the fatal pandemic, translate their symptoms under uncertainty for the worst and develop gloomier health outlooks.

Race is an important influencer in this study. Among all 3 groups, the percentage of Blacks was highest in the hospitalized group, a phenomenon seen in other inpatient COVID studies. ${ }^{20-24}$ Nevertheless, those of Black race reported significantly higher energy scores and emotional wellbeing scores in the adjusted models, as is also seen in other studies among those receiving dialysis ${ }^{25}$ and those with ischemic heart disease. ${ }^{26}$

Despite the pandemic being less than a year old, there is already a significant body of published research describing the psychological sequelae of living and working through the pandemic on health care workers ${ }^{27-29}$; family members of health care workers $^{30}$; people with pre-existing mental health conditions $^{31}$; college students ${ }^{32}$; and people with disabilities and chronic conditions ${ }^{33}$ as well as population-based studies. ${ }^{34-36}$ However, there is a dearth of research on the impact on HRQoL of individuals living through the SARS-CoV-2 pandemic. This study clarifies that adverse HRQoL impact is experienced not just by those who contract SARS-CoV-2 but by individuals living with chronic disease as well as those who contract simple non-COVID-19 viral illness.

Future directions of interest would include prospectively following HRQoL scores as the pandemic progresses across groups to see if HRQoL recovers or worsens as the pandemic progresses, and particularly for patients who have recovered post-SARS-CoV-2 as we seek to further understand the long-term sequelae of this novel pathogen.

\section{Limitations}

There were several limitations to this research. This was a single center study conducted in a crosssectional manner at a major academic tertiary referral medical center and may not be representative of patient populations in other settings. As with most survey research, a large number of people were contacted to reach the required completion rate for statistical power. We did not account for possible important differences in prepandemic health and comorbidities among those in the groups. We did not measure HRQoL before the pandemic, so individual comparisons between prepandemic and now are not possible.

\section{Conclusion}

HRQoL, as measured by the SF-36, was reduced in all 3 of our population groups. Importantly, we demonstrate that emotional/mental health domains were more severely depressed than the physical functioning domains across all groups.

As our public health response and mitigation strategies to the COVID-19 pandemic continue to evolve, it is important that the impact on HRQoL is understood and incorporated. Furthermore, the SF-36 measures can be transformed into utilities to be used in cost analyses for future predictions of economic recovery.

To see this article online, please go to: http://jabfm.org/content/ 34/3/509.full.

\section{References}

1. Blumenthal D, Fowler EJ, Abrams M, Collins SR. Covid-19-implications for the health care system. N Engl J Med 2020;383:1483-8. Erratum in: N Engl J Med 2020;383:1698.

2. Miller IF, Becker AD, Grenfell BT, Metcalf CJE. Disease and healthcare burden of COVID-19 in the United States. Nat Med 2020;26:1212-7.

3. Beigel JH, Tomashek KM, Dodd LE, et al. Remdesivir for the treatment of Covid-19-final report. N Engl J Med 2020;383:1813-26.

4. Nguyen HC, Nguyen MH, Do BN, et al. People with suspected COVID-19 symptoms were more likely depressed and had lower health-related quality of life: the potential benefit of health literacy. JCM 2020;9:965.

5. Suzuki Y, Maeda N, Hirado D, Shirakawa T, Urabe Y. Physical activity changes and its risk factors among community-dwelling Japanese older adults during the COVID-19 epidemic: associations with subjective well-being and health-related quality of life. IJERPH 2020;17:6591.

6. Arnold DT, Hamilton FW, Milne A, et al. Patient outcomes after hospitalisation with COVID-19 and implications for follow-up: results from a prospective UK group. Thorax. 2020. https://thorax. bmj.com/content/76/4/399. 
7. Hays RD, Sherbourne CD, Mazel R. User's manual for the Medical Outcomes Study (MOS) core measures of health-related quality of life. Santa Monica, CA: RAND Corporation; 1995. https://www.rand. org/pubs/monograph_reports/MR162.html.

8. McHorney CA, Ware JE, Jr, Raczek AE. The MOS 36-item short-form health survey (SF-36): II. Psychometric and clinical tests of validity in measuring physical and mental health constructs. Med Care 1993;31:247-63.

9. Kazis LE, Lee A, Spiro A, et al. Measurement comparisons of the medical outcomes study and veterans SF-36 health survey. Health Care Financ Rev 2004;25:43-58.

10. Hawthorne G, Densley K, Pallant JF, Mortimer D, Segal L. Deriving utility scores from the SF-36 health instrument using Rasch analysis. Qual Life Res 2008;17:1183-93.

11. McDonough CM, Tosteson AN. Measuring preferences for cost-utility analysis: how choice of method may influence decision-making. Pharmacoeconomics 2007;25:93-106.

12. Trikkalinou A, Papazafiropoulou AK, Melidonis A. Type 2 diabetes and quality of life. World J Diabetes 2017;8:120-9.

13. Health Department, Washtenaw County, Michigan. https://www.washtenaw.org/3108/Cases. Accessed December 22, 2020.

14. Jenkinson C, Coulter A, Wright L. Short form 36 (SF36) health survey questionnaire: normative data for adults of working age. BMJ 1993;306:1437-40.

15. RAND scoring of sf36. https://www.rand.org/ health-care/surveys_tools/mos/36-item-short-form/ scoring.html.

16. Dell Inc. Dell Statistica (data analysis software system) Version 13 [software]. 2015. software.dell.com.

17. Svedbo Engström M, Leksell J, Johansson UB, et al. Health-related quality of life and glycaemic control among adults with type 1 and type 2 diabetes-a nationwide cross-sectional study. Health Qual Life Outcomes 2019;17:141.

18. Adriaanse MC, Drewes HW, van der Heide I, Struijs JN, Baan CA. The impact of comorbid chronic conditions on quality of life in type 2 diabetes patients. Qual Life Res 2016;25:175-82.

19. Chen KY, Li T, Gong FH, Zhang JS, Li XK. Predictors of health-related quality of life and influencing factors for COVID-19 patients, a follow-up at one month. Front Psychiatry 2020;11:668.

20. Muñoz-Price LS, Nattinger AB, Rivera F, et al. Racial disparities in incidence and outcomes among patients with COVID-19. JAMA Netw Open 2020;3:e2021892.

21. Double jeopardy: COVID-19 and behavioral health disparities for Black and Latino communities in the U.S. https://www.samhsa.gov/sites/default/files/ covid19-behavioral-health-disparities-black-latinocommunities.pdf.

22. Ingraham NE, Purcell LN, Karam BS, et al. Racial/ethnic disparities in hospital admissions from COVID-19 and determining the impact of neighborhood deprivation and primary language. medRxiv 2020.09.02.20185983. [Preprint]. 2020.

23. Price-Haywood EG, Burton J, Fort D, Seoane L. Hospitalization and mortality among Black patients and White patients with Covid-19. N Engl J Med 2020;382:2534-43.

24. Gold JAW, Wong KK, Szablewski CM, et al. Characteristics and clinical outcomes of adult patients hospitalized with COVID-19-Georgia. MMWR 2020;69:545-50.

25. Unruh M, Miskulin D, Yan G, et al. Racial differences in health-related quality of life among hemodialysis patients. Kidney Int 2004;65: 1482-91.

26. Ohldin A, Young B, Derleth A, et al. Ethnic differences in satisfaction and quality of life in veterans with ischemic heart disease. J Natl Med Assoc 2004;96:799-808.

27. Chew NWS, Lee GKH, Tan BYQ, et al. A multinational, multicentre study on the psychological outcomes and associated physical symptoms amongst healthcare workers during COVID-19 outbreak. Brain Behav Immun 2020;88:559-65.

28. Amerio A, Bianchi D, Santi F, et al. Covid-19 pandemic impact on mental health: a web-based crosssectional survey on a sample of Italian general practitioners. Acta Biomed 2020;91:83-8.

29. De Sio S, Buomprisco G, La Torre G, et al. The impact of COVID-19 on doctors' well-being: results of a web survey during the lockdown in Italy. Eur Rev Med Pharmacol Sci 2020;24:7869-79.

30. Ying Y, Ruan L, Kong F, Zhu B, Ji Y, Lou Z. Mental health status among family members of health care workers in Ningbo, China, during the coronavirus disease 2019 (COVID-19) outbreak: a cross-sectional study. BMC Psychiatry 2020;20:379.

31. Termorshuizen JD, Watson HJ, Thornton LM, et al. Early impact of COVID-19 on individuals with self-reported eating disorders: a survey of $\sim 1,000$ individuals in the United States and the Netherlands. Int J Eat Disord 2020;53:1780-90.

32. Huckins JF, daSilva AW, Wang W, et al. Mental health and behavior of college students during the early phases of the COVID-19 pandemic: longitudinal smartphone and ecological momentary assessment study. J Med Internet Res 2020;22:e20185.

33. Umucu E, Lee B. Examining the impact of COVID-19 on stress and coping strategies in individuals with disabilities and chronic conditions. Rehabil Psychol 2020;65:193-8. 
34. Wang C, Pan R, Wan X, et al. Immediate psychological responses and associated factors during the initial stage of the 2019 coronavirus disease (COVID19) epidemic among the general population in China. IJERPH 2020;17:1729.

35. El-Zoghby SM, Soltan EM, Salama HM. Impact of the COVID-19 pandemic on mental health and social support among adult Egyptians. J Community Health 2020;45:689-95.

36. Alkhamees AA, Alrashed SA, Alzunaydi AA, Almohimeed AS, Aljohani MS. The psychological impact of COVID-19 pandemic on the general population of Saudi Arabia. Compr Psychiatry 2020;102:152192. 
Appendix. Diagnostic Criteria for COVID-19 Patients among Hospitalized Patients

Patients that were considered positive for COVID-19 were those that had a positive result from a lab-based polymerase chain reaction (PCR) test collected by nasopharyngeal swab or sputum as reported by the
Michigan Department of Health and Human Services, or by a validated lab-based PCR test of a nasopharyngeal swab from either Viracor or Michigan Medicine. Additionally, our cohort included patients who were transferred from other hospitals and hence had their COVID testing done externally. 